\author{
Tomasz Sosnowski*
}

\title{
RYNKOWE EFEKTY IMPLEMENTACJI STRATEGII CZĘŚCIOWEGO I PEŁNEGO WYJŚCIA Z INWESTYCJI FUNDUSZY PRIVATE EQUITY METODĄ PIERWSZEJ OFERTY PUBLICZNEJ
}

\section{WPROWADZENIE}

Analiza działalności funduszy private equity wskazuje na ich wzrastającą rolę i znaczenie na polskim rynku kapitałowym oraz na istotną rolę Giełdy Papierów Wartościowych w Warszawie w procesie dezinwestycji. Między działalnością funduszy private equity a rynkiem kapitałowym występują określone relacje, przynoszące bilateralne korzyści. Mający miejsce rozwój publicznego rynku papierów wartościowych wspiera ekspansję działalności funduszy private equity zapewniając im atrakcyjną ścieżkę wyjścia z inwestycji. $\mathrm{Z}$ drugiej strony, fundusze dążąc do wprowadzenia akcji spółek portfelowych do publicznego obrotu sprzyjają rozwojowi tego rynku.

Zasadniczym celem opracowania jest ocena rynkowych efektów procesów dezinwestycji funduszy private equity realizowanych metodą pierwszej oferty publicznej na Giełdzie Papierów Wartościowych w Warszawie.

Dla realizacji celu opracowania sformułowana została hipoteza badawcza stwierdzająca, iż dla spółek wobec których zastosowana została strategia pełnego wyjścia z inwestycji funduszu private equity obserwowane są wyższe długoterminowe stopy zwrotu $\mathrm{z}$ akcji w porównaniu ze spółkami portfelowymi funduszy private equity, gdzie zrealizowana została formuła częściowego wyjścia z inwestycji.

Postawiona hipoteza badawcza nabiera istotnego znaczenia dla analizy efektywności działalności inwestycyjnej funduszy private equity. Publiczny rynek papierów wartościowych umożliwia implementację strategii dezinwestycji

* Dr, Uniwersytet Łódzki, Wydział Ekonomiczno-Socjologiczny, Katedra Analizy i Strategii Przedsiębiorstwa. 
o różnej dynamice i zakresie. Przybierać może ona bowiem formę całkowitego lub częściowego wyjścia $\mathrm{z}$ inwestycji. $\mathrm{Z}$ perspektywy inwestora giełdowego sytuacja ta może wpływać na postrzeganie ryzyk związanych z inwestycjami w akcje poszczególnych grup spółek, wpływając na ich wycenę rynkową, która wprost znajduje odzwierciedlenie w poziomie efektywności inwestycji dokonywanych przez fundusze private equity. Dla przedsiębiorstw udziałowych, w których proces dezinwestycji nie został ukończony szczególnie istotne może być ryzyko związane z pojawieniem się na rynku dodatkowej podaży akcji z portfela inwestycyjnego funduszy private equity, tzw. nawis podażowy.

\section{KLUCZOWA ROLA PROCESU DEZINWESTYCJI W DZIAŁALNOŚCI FUNDUSZY PRIVATE EQUITY}

Fundusze private equity są podmiotami inwestującymi zgromadzone wcześniej zasoby kapitałowe, ludzkie i informacyjne w przedsiębiorstwa wyróżniające się znaczącym potencjałem wzrostu wartości rynkowej. Istota ich działalności polega na poszukiwaniu, finansowaniu i wspieraniu rozwoju przedsiębiorstw będących narzędziami Schumpeterowskiej twórczej destrukcji ${ }^{1}$. Wspomagając rozwój tych przedsiębiorstw działają one również w interesie swoich właścicieli i wierzycieli, którzy oczekują odpowiedniej stopy zwrotu z kapitału powierzonego w zarządzanie.

Określenie private equity odnosi się do działalności profesjonalnych podmiotów polegającej na inwestowaniu z reguły w papiery wartościowe o charakterze właścicielskim. Jest to wnoszony przez inwestorów zewnętrznych do innowacyjnych przedsiębiorstw kapitał własny w celu osiąnnięcia ponadprzeciętnego zysku kapitałowego w momencie sprzedaży obejmowanych w zamian akcji bądź udziałów. Przyjmuje się, iż do grupy inwestycji private equity zalicza się trzy segmenty inwestycji kapitałowych: venture capital, buyout capital oraz mezzanine capital ${ }^{2}$.

Rolą funduszy private equity jest stworzenie warunków skutecznego przepływu kapitału pomiędzy inwestorami dysponującymi określonymi zasobami kapitałowymi a spółkami potrafiącymi efektywnie go wykorzystać ${ }^{3}$, przynosząc jednocześnie korzyści wszystkim stronom zaangażowanym $w$ dane przedsię-

${ }^{1}$ M. Panfil, Globalizacja inwestycji venture capital, [w:] A. S z able w s ki (red.), Migracja kapitatu w globalnej gospodarce, Difin, Warszawa 2009, s. 169.

${ }^{2}$ D. Glad st on e, L. Glad st on e, Venture capital Handbook: An Enterpreneur's Guide to Raising Venture capital, Financial Times Prentice Hall, Londyn-New York 2001, s. 5; L. E. S w e $\mathrm{droe}$, J. Kizer, The only guide to alternative investments you'll ever need, Bloomberg Press, New York 2008, s. 125; D. R. Jobman, The Handbook of Alternative Investment, John Wiley\&Sons, Inc., New York 2002, s. 141.

${ }^{3}$ G. W. Fen n, N. Li an g, S. Prow s e, The Economics of the Private equity Market, „Federal Reserve Bulletin”, January 1996, s. 3-5. 
wzięcie. $Z$ jednej strony fundusze gromadzą kapitał i przyciagają dużą liczbę inwestorów, oferując im wpływ na zarządzanie powierzonymi przez nich pieniędzmi, raportowanie i monitoring inwestycji, zaś z drugiej strony fundusze te zapewniają profesjonalne zasady selekcji obiecujących projektów inwestycyjnych oraz wdrażają efektywne strategie budowania wartości rynkowej wspieranych przedsiębiorstw ${ }^{4}$.

Specyficzną cechą inwestycji funduszy private equity jest różnorodność treści, form i sposobów ich działania. Wspieranie rozwoju przedsiębiorstw udziałowych następuje nie tylko przez dopływ środków pieniężnych, lecz również poprzez know-how w zakresie zarządzania ${ }^{5}$ oraz inne formy wsparcia kapitałem menedżerskim ${ }^{6}$. Przedsiębiorstwa pozyskujące kapitał z funduszu private equity tworzą swoiste keirestu, gdyż włączane są rozległej sieci kontaktów biznesowych, a często budują rozległe powiązania biznesowe z innymi przedsiębiorstwami udziałowymi z portfolio inwestycyjnego danego funduszu ${ }^{7}$.

Inwestycje funduszy private equity charakteryzują się określonym czasem trwania i zawsze podejmowane są $\mathrm{z}$ zamiarem odsprzedaży posiadanych w portfelu inwestycyjnym aktywów. W praktyce prowadzenia działalności inwestycyjnej funduszy private equity wskazuje się na wiele różnorodnych czynników mających wpływ na czas zaangażowania kapitałowego funduszu w spółkę portfelową ${ }^{8}$ Badania przeprowadzone wśród europejskich inwestorów venture capital pokazuja, iż planowany okres inwestycji w większości przypadków wynosi od 2 do 5 lat $^{9}$. Zaznaczyć jednak należy, iż dla funduszu którego celem jest realizacja zamierzonego zysku w najbardziej dogodnym momencie, konieczne jest określenie terminu wyjścia $\mathrm{z}$ inwestycji nie tyle przez podanie konkretnej daty, ale przede wszystkim na podstawie osiagnięcia określonych efektów ekonos. 87.

${ }^{4}$ M. Panfil, Fundusze private equity. Wptyw na wartość spótki, Difin, Warszawa 2005,

${ }^{5}$ L. Le w a n d o w s ka, Niekonwencjonalne formy finansowania przedsiębiorczości, ODiDK Sp. z o.o., Gdańsk 2000, s. 111.

${ }^{6}$ Zob. J. Ortgiese, Value Added by Venture Capital Firms, JOSEF EUL VERLAG, Lohmar-Köln 2007, s. 47.

${ }^{7}$ L. Li in s e y, The Venture Capital Keiretsu Effect: An Empirical Analysis of Strategic Alliances Among Portfolio Firms, SIEPR Discussion Paper No. 02-17, Stanford University, November 2002, s. 1-46; D. H. H s u, What Do Entrepreneurs Pay for Venture capital Affiliation?, „The Journal of Finance", August 2004, vol. LIX, no. 4, s. 1805-1844; Y. V. Hochberg, A. Lj u n g q v is t, Y. Lu, Venture Capital Networks and Investment Performance, „The Journal of Finance" 2007, vol. 62, no. 1, s. 251-301.

${ }^{8}$ D. J. C u m ming, J. G. M a c In to s h, Venture capital investment duration in Canada and the United States, „Journal of Multinational Financial Management” 2001, vol. 11, s. 445-463; P. Go mpers, Grandstanding in the venture capital industry, ,Journal of Financial Economics” 1996, vol. 42, s. 133-156; P. Go mpers, Optimal Investment, Monitoring, and the Staging of Venture capital, „Journal of Finance” 1995, vol. 50, issue 5, s. 1461-89; D. J. Cu mming, G. Fle ming, A. Schwienbacher, Liquidity Risk and Venture capital Finance, „Financial Management" 2005, vol. 34, issue 4, s. 77-105.

${ }^{9}$ Survey of the Economic and Social Impact of Venture Capital in Europe, Research Paper EVCA, Zaventem, Belgium 2002, s. 11. 
micznych ${ }^{10}$. Długość zaangażowania kapitałowego funduszu private equity w spółkę portfelową jest kwestią indywidualną, niewątpliwie związaną z potencjałem wzrostu jej wartości rynkowej ${ }^{11}$.

Specyfiką działalności funduszy private equity jest odłożona w czasie realizacja zysku kapitałowego z inwestycji. Jest on realizowany dopiero w końcowej części całego cyklu inwestycyjnego tj. w fazie dezinwestycji, a jego podstawowym źródłem jest nadwyżka rynkowej wartości kapitału przedsiębiorstwa udziałowego w momencie wyjścia z inwestycji nad sumą zainwestowanego kapitału.

Zysk kapitałowy z tych inwestycji osiagany jest dopiero w momencie zbycia udziałowych papierów wartościowych, przez co czas i rozmiar dezinwestycji nabierają szczególnego znaczenia dla inwestorów. Wyjście z inwestycji stanowi finalny etap w cyklu życia każdego przedsięwzięcia kapitałowego realizowanego przez fundusze private equity ${ }^{12}$. Dezinwestycja jest bowiem swoistego rodzaju ukoronowaniem starań interesariuszy przedsiębiorstwa udziałowego o realizację określonej rynkowej rentowności kapitału własnego, ulokowanego uprzednio w niepubliczną spółkę kapitałową rokującą nadzieję na wzrost wartości rynkowej.

Wyjście z inwestycji stanowi niezwykle istotny element strategii działania funduszy private equity. Rozwój rynku kapitału podwyższonego ryzyka, a także inwestycje dokonywane przez fundusze, uzależnione są bowiem od możliwości późniejszego wyjścia $\mathrm{z}$ inwestycji ${ }^{13}$ i realizacji oczekiwanej stopy zwrotu. Ostatecznie o sukcesie przedsięwzięcia decyduje rynek. L. Lewandowska wskazuje, że aktualność zachowuje teza L. Misesa, według której dopiero cena rynkowa faktycznie przyznana produktowi określa trafność podjętej decyzji inwestycyjnej, a zarazem i decyzji finansowej ${ }^{14}$. Dla funduszy private equity produktem tym są udziałowe papiery wartościowe wspieranych przedsiębiorstw.

\section{PIERWSZA OFERTA PUBLICZNA JAKO METODA REALIZACJI ZYSKU KAPITAŁOWEGO FUNDUSZY PRIVATE EQUITY}

Wyjście z inwestycji przybierać może zróżnicowane formy i przez to stwarzać funduszom private equity odmienne szanse na osiagnięcie sukcesu ekonomicznego, a wybór odpowiedniej metody dezinwestycji uzależniony jest od

${ }^{10}$ K. Sobańska, P. Sieradzan, Inwestycje private equity/venture capital, Key Text, Warszawa 2004, s. 113.

${ }^{11} \mathrm{~J}$. H. Cochrane, The risk and return of venture capital, ,Journal of Financial Economics" 2005, vol. 75, s. 3-52.

${ }^{12}$ G. W. Fen n, N. Li ang, S. Prow se, op. cit., s. 29.

${ }^{13}$ P. Go mpers, J. Lerner, The Venture capital Cycle, MIT Press, Cambridge Massachusetts 2006, s. 345; B. S. B l a ck, R. J. Gil so n, Venture capital and the structure of capital markets: Banks versus stock markets, ,Journal of Financial Economics” 1998, vol. 47, s. 254.

${ }^{14}$ L. Lew and ow ska, op. cit., s. 115. 
zespołu czynników i wzajemnie powiązanych uwarunkowań ${ }^{15}$. Fundusze private equity mają do dyspozycji pięć podstawowych metod zakończenia współpracy ze spółką portfelową ${ }^{16}$. Są to:

- wprowadzenie akcji spółki do publicznego obrotu i ich sprzedaż za pośrednictwem giełdy papierów wartościowych,

- sprzedaż spółki strategicznemu inwestorowi branżowemu,

- wykup menedżerski,

- zbycie udziałów na rzecz innego inwestora finansowego oraz

- umorzenie udziałów/likwidacja spółki.

Wprowadzenie spółki portfelowej na giełdę, a następnie sprzedaż posiadanych przez fundusz akcji za jej pośrednictwem traktowane jest przez polskie firmy zarządzające funduszami private equity jako jedna z podstawowych i ważnych metod wyjścia z inwestycji (zob. rys. 1). Nie jest to jednak metoda uniwersalna, która może być wykorzystana do realizacji zysku kapitałowego z każdej inwestycji. Znajduje ona zastosowanie tylko do takich przedsiębiorstw udziałowych, które osiagnęły znamienny sukces rynkowy i spotkały się z zainteresowaniem wymagających nabywców na publicznym rynku papierów wartościowych. Oferta publiczna to właściwa droga - jak wskazuje K. Sobańska i P. Sieradzan - dla spółek w miarę dużych, o znaczącym poziomie rentowności, rosnących zyskach, przejrzystych strukturach organizacyjnych i przepływach finansowych ${ }^{17}$.

Sprzedaż akcji za pośrednictwem giełdy papierów wartościowych uchodzi za preferowaną przez zarządzających inwestycjami funduszy private equity metodę realizacji zysku kapitałowego, a czasami postrzega się ją jako niemalże „Święty Graal" "18. Związane jest to z jej licznymi zaletami oraz przewagami w stosunku do pozostałych form dezinwestycji. Wśród praktyków gospodarczych, jak i w literaturze przedmiotu panuje konsensus co do licznych korzyści dla funduszy private equity płynących z realizacji publicznych ofert sprzedaży posiadanych akcji. Wskazać można głównie na ${ }^{19}$ :

- możliwość uzyskania wysokiej wyceny spółki,

- $\mathrm{z}$ reguły jest to preferowana przez kierownictwo spółki forma zakończenia współpracy,

- rozliczne korzyści marketingowe dla spółki i funduszu,

${ }^{15}$ Zob. T. S o s n o w s ki, Uwarunkowania decyzji funduszy private equity o wyborze metody dezinwestycji, [w:] J. D u raj (red.), Prace z zakresu ekonomiki i zarzadzania przedsiębiorstwem, „Acta Universitatis Lodziensis”, Folia Oeconomica 256, Wydawnictwo Uniwersytetu Łódzkiego, Łódź 2011, s. 71-92.

${ }^{16}$ Por. P. Z a s ęp a, Venture capital - sposoby dezinwestycji, CeDeWu.pl Wydawnictwa Fachowe, Warszawa 2010, s. 90-91; K. S o b ań s k a, P. S i e r a d z a n, op. cit., s. 115.

${ }^{17}$ K. S obań ska, P. Sier ad zan, op. cit., s. 122.

${ }^{18}$ J. W a 11, J. S mith, Better exits, Price Waterhouse Corporate Finance for EVCA, 1997, s. 8.

${ }^{19}$ Zob. S. P ov a ly, Private equity exits: Divestment process management for leveraged buyouts, Springer, Berlin Heidelberg 2007, s. 252-253. 
- wzbudzenie zainteresowania spółką podmiotów aktywnych na rynku fuzji i przejęć,

- dostęp spółki do nowego źródła finansowania.

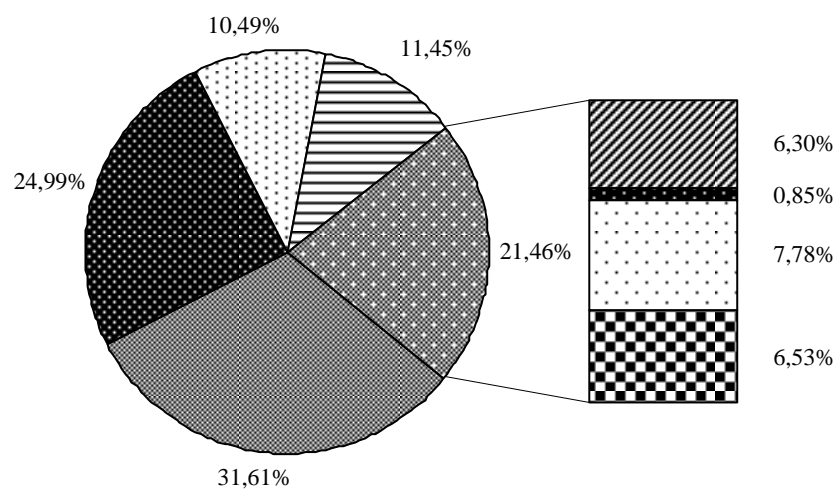

\footnotetext{
圆 Sprzedaż inwestorowi branżowemu

Sprzedaż w drodze emisji publicznej

$\square$ Likwidacja spółki/umorzenie udziałów

曰Sprzedaż innemu funduszowi private equity

$\square$ Spłata inwestorowi preferencyjnych pożyczek

Sprzedaż insty tucji finansowej

口 Sprzedaż zarządowi spółki (buy-back)

$\square$ Inne metody dezinwestycji
}

Rys. 1. Udział poszczególnych metod dezinwestycji stosowanych przez fundusze private equity mających siedzibę w Polsce w latach 2002-2010

Źródło: opracowanie własne na podstawie: EVCA Yearbook 2003-2011, European Private Equity \& Venture Capital Association, Zaventem, Belgium.

Powszechna jest również świadomość co do ograniczeń związanych z możliwościami wyjścia z inwestycji tą metodą pierwszej oferty publicznej ${ }^{20}$. Poza takimi czynnikami jak skomplikowane i czasochłonne procedury dopuszczenia akcji do publicznego obrotu oraz wysokie koszty tego typu transakcji wskazuje się na jeszcze jedno bardzo ważne ograniczenie. Wyjście z inwestycji za pośrednictwem rynku giełdowego wiąże się na ogół z rozłożoną w czasie redukcją zaangażowania kapitałowego funduszu private equity ${ }^{21}$. Natychmiastowe wyjście z inwestycji uznawane jest za mało prawdopodobne.

Zasadniczą przesłanką skłaniającą ku takiemu stanowisku jest występowanie znaczącej asymetrii informacji pomiędzy właścicielami spółki przed jej upu-

${ }^{20}$ Ibidem.

${ }^{21}$ Zob. P. Go mpers, J. Lern er, op. cit., s. 423; M. W r ze s iń s ki, Kapitat podwyższonego ryzyka. Proces inwestycyjny i efektywność, Szkoła Główna Handlowa w Warszawie, Warszawa 2008, s. 231; D. J. Cumming, J. G. Mac Intosh, A cross-country comparison..., op. cit., s. $511-548$. 
blicznieniem a nabywcami akcji oferowanych na publicznym rynku papierów wartościowych, negatywnie wpływającej na wycenę rynkową spółki ${ }^{22}$. Fundusz private equity jest stroną uprzywilejowaną $\mathrm{w}$ stosunku do inwestorów giełdowych w zakresie dostępu do informacji i możliwości jej wykorzystania w procesach dezinwestycji. Posiada on $\mathrm{z}$ reguły pełniejszą wiedzę o konkurentach, klientach, trudnościach działania oraz perspektywach dalszego rozwoju. Fundusz private equity, pozostając akcjonariuszem spółki po jej upublicznieniu, przekazuje sygnał otoczeniu rynkowemu, iż nadal pozytywnie postrzega perspektywy rozwoju spółki i wzrostu jej wartości rynkowej, wpływając przez to na zmniejszenie negatywnych skutków luki informacyjnej ${ }^{23}$.

Utrzymanie częściowego zaangażowania kapitałowego funduszu private equity w spółce portfelowej po wprowadzeniu jej akcji do publicznego obrotu jest źródłem pewnych ryzyk, zarówno dla funduszu, jak i pozostałych bieżących oraz potencjalnych akcjonariuszy. Fundusz jest narażony na ryzyko związane ze zmienną koniunkturą giełdową, a wahania kursów akcji mogą wpływać na poziom osiagganego zwrotu z inwestycji w daną spółką. Mając na uwadze intencje funduszu związane $\mathrm{z}$ realizacją procesu dezinwestycji, inwestorzy giełdowi mogą obawiać się pojawienia się na rynku znaczącej podaży akcji danej spółki. Ryzyko związane $\mathrm{z}$ tzw. nawisem podażowym może stanowić istotną barierę wzrostu wyceny rynkowej danej spółki. Rozpoznanie długoterminowych rynkowych efektów dezinwestycji realizowanych $\mathrm{z}$ różnym natężeniem stanowi relewantną przesłankę oceny efektywności procesów wyjścia z inwestycji funduszy private equity za pośrednictwem publicznego rynku papierów wartościowych.

\section{PODSTAWY METODYCZNE BADAŃ NAD RYNKOWYMI EFEKTAMI WYKORZYSTANIA STRATEGII CZĘŚCIOWEGO I PEŁNEGO WYJŚCIA Z INWESTYCJI FUNDUSZY PRIVATE EQUITY METODĄ PIERWSZEJ OFERTY PUBLICZNEJ}

Badania empiryczne zostały przeprowadzone na grupie 26 spółek portfelowych funduszy private equity, których pierwsze notowanie na Giełdzie Papierów Wartościowych w Warszawie odbyło się w latach 2002-2010. Badane podmioty posiadały główną siedzibę działalności w Polsce, a przed dopuszczeniem do publicznego obrotu przeprowadziły publiczną ofertę sprzedaży akcji i/lub publiczną subskrypcję akcji. Ocena rynkowych efektów dezinwestycji funduszy private equity objęła okres około 3 lat po debiucie giełdowym spółki (750 sesji giełdowych).

${ }^{22}$ Zob. D. C u m m in g, S. J o h a n, Information asymmetries, agency costs and venture capital exit outcomes, „Venture capital” 2008, vol. 10, no. 3, s. 198.

${ }^{23}$ Zob. W. L. M e g g in s o n, K. A. W e is s, Venture capitalists certification in initial public offerings, ,Journal of Finance” 1991, vol. 46, s. 879-903. 
Za D. J. Cummingiem oraz J. G. MacIntoshem jako całkowite za całkowite wyjście z inwestycji uznano sytuację, kiedy fundusz private equity sprzedał wszystkie posiadane akcje spółki portfelowej w okresie nie przekraczającym jednego roku od jej debiutu giełdowego. Jeżeli po tym czasie fundusz nadal pozostawał akcjonariuszem $\mathrm{w}$ tej spółce, wówczas przyjęto, że strategia redukcji zaangażowania kapitałowego w spółkę portfelową przybrała formułę częściowego wyjścia $\mathrm{z}$ inwestycji ${ }^{24}$.

Do oceny efektów strategii częściowego i całkowitego wyjścia z inwestycji funduszu private equity za pośrednictwem publicznego rynku papierów wartościowych wykorzystane zostały skumulowane anormalne stopy zwrotu (CAR).

W celu wnioskowania dla wydzielonych w ramach próby badawczej grup podmiotów wykorzystano stopy zwrotu z akcji poszczególnych spółek na kolejnych sesjach, rozpoczynając od drugiego dnia notowań giełdowych. W badaniach nie została uwzględniona stopa zwrotu z pierwszego dnia notowań akcji spółki, w celu wykluczenia wpływu obserwowanego na wielu rynkach i w różnych okresach zjawiska niedowartościowania pierwszych ofert publicznych ${ }^{25}$.

Prosta stopa zwrotu, poza czynnikami specyficznymi dla danej spółki lub grupy spółek uwzględnia również zmiany uwarunkowań ogólnorynkowych, jakie miały miejsce $\mathrm{w}$ dniu debiutu giełdowego. Dla wyeliminowania wpływu tego czynnika na otrzymane wyniki zachodzi konieczność skorygowania zaobserwowanych stóp zwrotu o tzw. normalną stopę zwrotu. Powstała w ten sposób skorygowana stopa zwrotu z akcji została wyznaczona w następujący sposób:

$$
A \mathrm{R}_{i, t}=\mathrm{R}_{i, t}-E\left(\mathrm{R}_{i, t} \mid X_{t}\right)
$$

gdzie:

$A \mathrm{R}_{i, t} \quad-$ skorygowana stopa zwrotu $\mathrm{z}$ akcji $i$-tej spółki $\mathrm{w} t$ dniu notowań,

$\mathrm{R}_{i, t} \quad-$ stopa zwrotu z akcji $i$-tej spółki $\mathrm{w} t$ dniu notowań

$E\left(\mathrm{R}_{i, t} \mid X_{t}\right)$ - normalna stopa zwrotu w danym dniu notowań $i$-tej spółki.

W literaturze przedmiotu występuje wiele różnorodnych podejść do wyznaczania normalnej stopy zwrotu. Ogólnie podejścia te można podzielić na dwie

${ }^{24}$ Zob. D. J. Cumming, J. G. Mac Intosh, A cross-country comparison..., op. cit., s. 514-516.

${ }^{25}$ Zob. A. Lj ung q vi st, IPO underpricing, [w:] B. E. Eckbo (red.), Handbook of Corporate Finance: Empirical Corporate Finance, 2006, vol. A, chapter 7, s. 8-10; T. Lou gh ran, J. R. Ritter, K. Rydqvis t, Initial public offerings: International insights, „Pacific-Basin Finance Journal" 1994, vol. 2, s. 165-199; T. J. B o u l t o n, S. B. S m a rt, C. J. Z u t t e r, IPO underpricing and international corporate governance, „Journal of International Business Studies” 2010, vol. 41, s. 206-222; D. Sukacz, Pierwsze oferty publiczne na rynkach kapitatowych, CeDeWu.pl, Warszawa 2005, s. 82-84. 
grupy, modele statystyczne i modele ekonomiczne. W analizie zdarzeń na rynkach kapitałowych wykorzystuje się zwłaszcza model stałej średniej stopy zwrotu (ang. Constant Mean Return Model), model rynkowy (ang. Market Model), model wyceny aktywów kapitałowych (ang. Capital Asset Pricing Model) oraz model wyceny arbitrażowej (ang. Arbitrage Pricing Theory) ${ }^{26}$.

Do analizy rynkowych efektów pierwszych ofert publicznych aplikacja wskazanych rozwiązań jest niemożliwa ze względu na brak informacji o cenach rynkowych akcji spółki poprzedzających zdarzenie. Ze względu na specyfikę pierwszych ofert publicznych do wyznaczenia normalnych stóp zwrotu stosuje się model indeksowy, według którego normalna stopa zwrotu z akcji określonej spółki będzie równa stopie zwrotu z portfela rynkowego. W literaturze przedmiotu jako jej odpowiednik najczęściej wykorzystuje się stopę zwrotu z indeksu danej giełdy, jednakże należy zaznaczyć, że możliwe są również inne rozwiązania, a wybór podyktowany jest często dostępnością danych. W realizowanych badaniach jako stopa zwrotu z portfela rynkowego wykorzystana została stopa zwrotu z Warszawskiego Indeksu Giełdowego. Zastosowane formuły dla poszczególnych spółek, jak i grup podmiotów przybrały zatem postać:

$$
\begin{aligned}
& A \mathrm{R}_{i, t}=R_{i, t}-\frac{W I G_{i, t}}{W I G_{i, t-1}}-1 \\
& \overline{A \mathrm{R}_{t}}=n^{-1} \sum_{i=1}^{n} A \mathrm{R}_{i, t}=n^{-1} \sum_{i=1}^{n}\left(R_{i, t}-\frac{W I G_{i, t}}{W I G_{i, t-1}}-1\right)
\end{aligned}
$$

gdzie:

$\overline{A \mathrm{R}_{t}} \quad$-średnia skorygowana stopa zwrotu $\mathrm{z}$ akcji w $t$ dniu notowań,

$n \quad$ - liczba spółek

$W I G_{i, t}$ - wartość indeksu WIG na zamknięciu notowań $i$-tej spółki w dniu $t$,

$W I G_{i, t-1}$ - wartość indeksu WIG na zamknięciu notowań $i$-tej spółki w dniu $t-1$,

pozostałe oznaczenia jak wyżej.

Dla pokazania tendencji w zakresie kształtowania się stóp zwrotu w analizowanych przekrojach klasyfikacyjnych przeprowadzona została agregacja otrzymanych wyników, co pozwoliło na pokazanie stóp zwrotu w sposób narastający. Otrzymana w ten sposób skumulowana nadzwyczajna stopa zwrotu wyznaczona została zgodnie ze wzorem:

${ }^{26}$ A. C. M a c kin lay, Event Studies in Economics and Finance, ,Journal of Economic Literature", March 1997, vol. XXXV, s. 17-19. 


$$
\overline{C A \mathrm{R}_{\langle 2, T\rangle}}=\sum_{t=2}^{T} \overline{A \mathrm{R}_{t}}
$$

gdzie:

$\overline{C A \mathrm{R}_{\langle 2, T\rangle}}$ - przeciętna skumulowana stopa zwrotu w okresie od 2 do pozostałe oznaczenia jak wyżej.

Informacje dotyczące poziomu dziennych stóp zwrotu z akcji poszczególnych spółek oraz stóp zwrotu opisujących zmiany indeksu WIG na poszczególnych sesjach giełdowych wykorzystane $\mathrm{w}$ badaniu pochodziły $\mathrm{z}$ internetowego portalu informacyjnego prowadzonego przez Polską Agencję Prasową we współpracy z Giełdą Papierów Wartościowych w Warszawie SA http://www.gpwinfostrefa.pl. $\mathrm{W}$ badaniach notowanie praw do akcji (PDA) było traktowane równorzędnie z notowaniem akcji, aczkolwiek jeżeli oba rodzaje papierów wartościowych były notowane jednocześnie, do obliczeń wykorzystana została stopa zwrotu $\mathrm{z}$ akcji. Ostatnia sesja giełdowa uwzględniona $\mathrm{w}$ badaniach odbyła się 30 marca 2012 r. Jeżeli akcje danej spółki zostały wycofane z publicznego obrotu przed tym terminem, w badaniach uwzględniono tylko sesje, w których dostępna była informacja o stopie zwrotu z akcji danej spółki.

\section{WYNIKI BADAŃ EMPIRYCZNYCH NAD RYNKOWYMI EFEKTAMI WYKORZYSTANIA STRATEGII CZECŚCIOWEGO I PEŁNEGO WYJŚCIA Z INWESTYCJI FUNDUSZY PRIVATE EQUITY METODĄ PIERWSZEJ OFERTY PUBLICZNEJ}

Pierwsza publiczna oferta sprzedaży akcji spółki portfelowej oraz wprowadzenie ich do publicznego obrotu w wielu przypadkach otwiera proces redukcji zaangażowania kapitałowego funduszu private equity w spółkę. Na podstawie informacji przekazywanych w formie raportów bieżących analizowanych spółek należy stwierdzić, iż $\mathrm{w}$ przeważającej części przedsiębiorstw udziałowych pierwsza oferta publiczna była stosowana jako częściowe wyjście z inwestycji (zob. rys. 2).

Analizując dane przedstawione na rys. 2 można wskazać, iż fundusze private equity zastosowały strategię całkowitego wyjścia z inwestycji wobec $8 \mathrm{z} 26$ badanych spółek portfelowych. W przypadku pozostałych podmiotów wykorzystana została strategia częściowego wyjścia z inwestycji, a okres kontynuacji zaangażowania kapitałowego funduszy private equity w rozważane spółki po wprowadzeniu ich akcji do publicznego obrotu był zróżnicowany.

Rozpoznanie rynkowych efektów realizowanych procesów dezinwestycji realizowanych za pośrednictwem publicznego rynku kapitałowego przy użyciu 
skumulowanych średnich stóp zwrotu wskazuje, iż kurs akcji spółek portfelowych funduszy private equity w okresie następującym po debiucie giełdowym kształtował się w zróżnicowany sposób. W większości analizowanego okresu skumulowane średnie stopy zwrotu były dodatnie (zob. rys. 3).

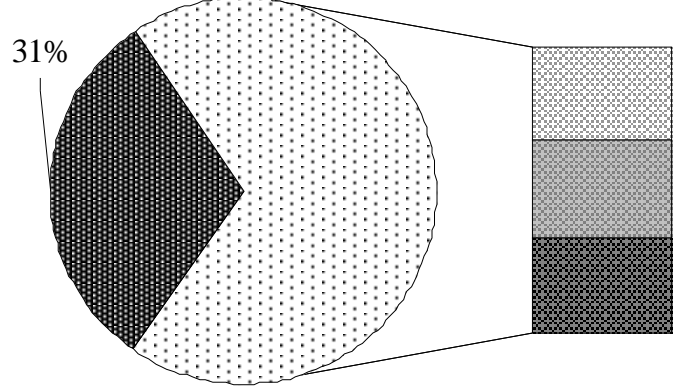

$69 \%$
Pełne wyjście z inwestycji

$23 \%$

12-36 miesięcy

$23 \%$

⿴囗十 Powyżej 36 miesięcy

$23 \%$

Inwestycje niezakończone*

okres kontynuacji zaangażowania kapitałowego funduszu private equity w spółkę po jej debiucie giełdowym wynosi od 21 do 54 miesięcy na dzień 30.03.2012 r.

Rys. 2. Pełna i częściowa dezinwestycja funduszu private equity w analizowanych spółkach

Źródło: opracowanie własne na podstawie raportów bieżących spółek.

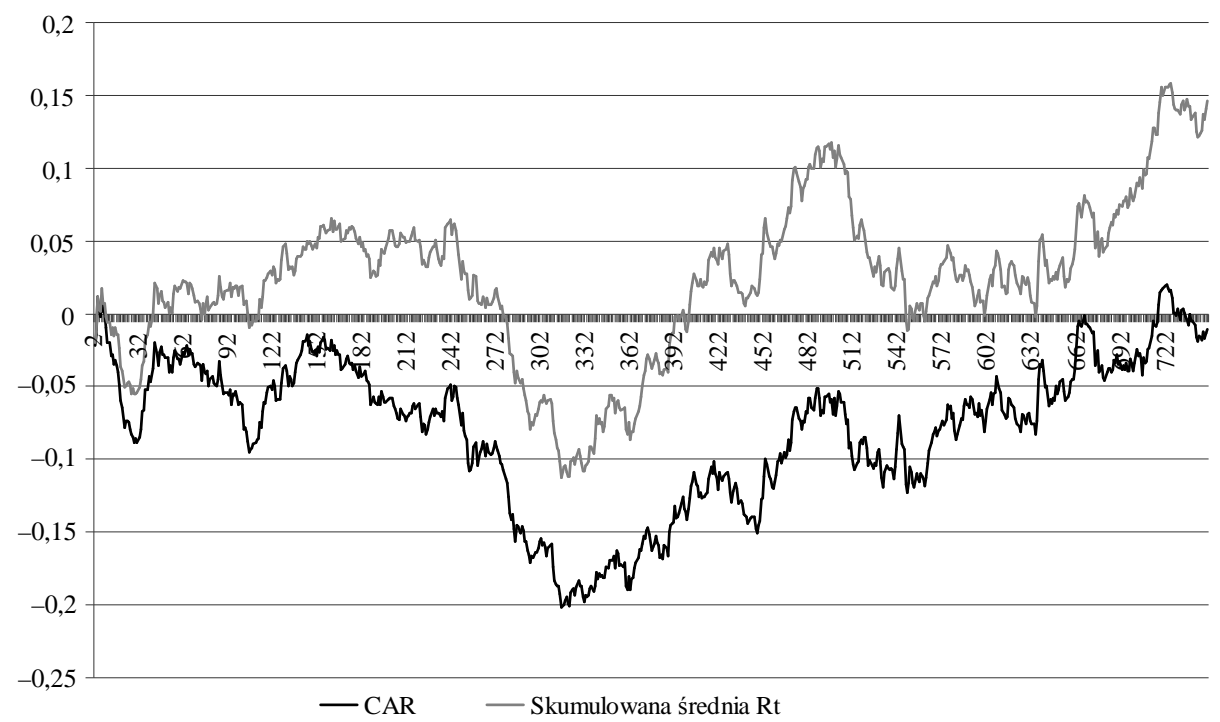

Rys 3. Skumulowane średnie i anormalne stopy zwrotu z akcji spółek portfelowych funduszy private equity dla pierwszych ofert publicznych w latach 2002-2010

Źródło: opracowanie własne na podstawie: http://www.gpwinfostrefa.pl. 
Analizując informacje zawarte na rys. 3 można zauważyć, iż skumulowana nadzwyczajna stopa zwrotu $\mathrm{z}$ akcji spółek portfelowych funduszy private equity w okresie do 145 dnia notowań charakteryzowała się zarówno wyraźnymi falami spadkowymi, jak i wzrostowymi, jednakże odznaczała się przeważnie wartościami ujemnymi. W kolejnych sesjach giełdowych można zaobserwować wyraźny trend spadkowy, który osiagnął swoje minimum na poziomie $-20,06 \%$ w 321 dniu notowań. Następnie można zaobserwować odwrócenie tendencji spadkowej i długotrwały trend wzrostowy skumulowanej anormalnej stopy zwrotu. Przekroczenie analizowanej miary powyżej poziomu zerowego zaobserwowane zostało dopiero po 717 sesji giełdowej, co w przeliczeniu na czas kalendarzowy daje niespełna 3 lata.

Porównując kształtowanie się skumulowanych anormalnych stóp zwrotu $\mathrm{z}$ akcji spółek portfelowych funduszy private equity wobec których zastosowana została strategia pełnego wyjścia $z$ inwestycji ze skumulowanymi stopami zwrotu z akcji pozostałych badanych spółek można zauważyć występowanie odmiennych tendencji w kształtowaniu się analizowanej zmiennej (zob. rys. 4).

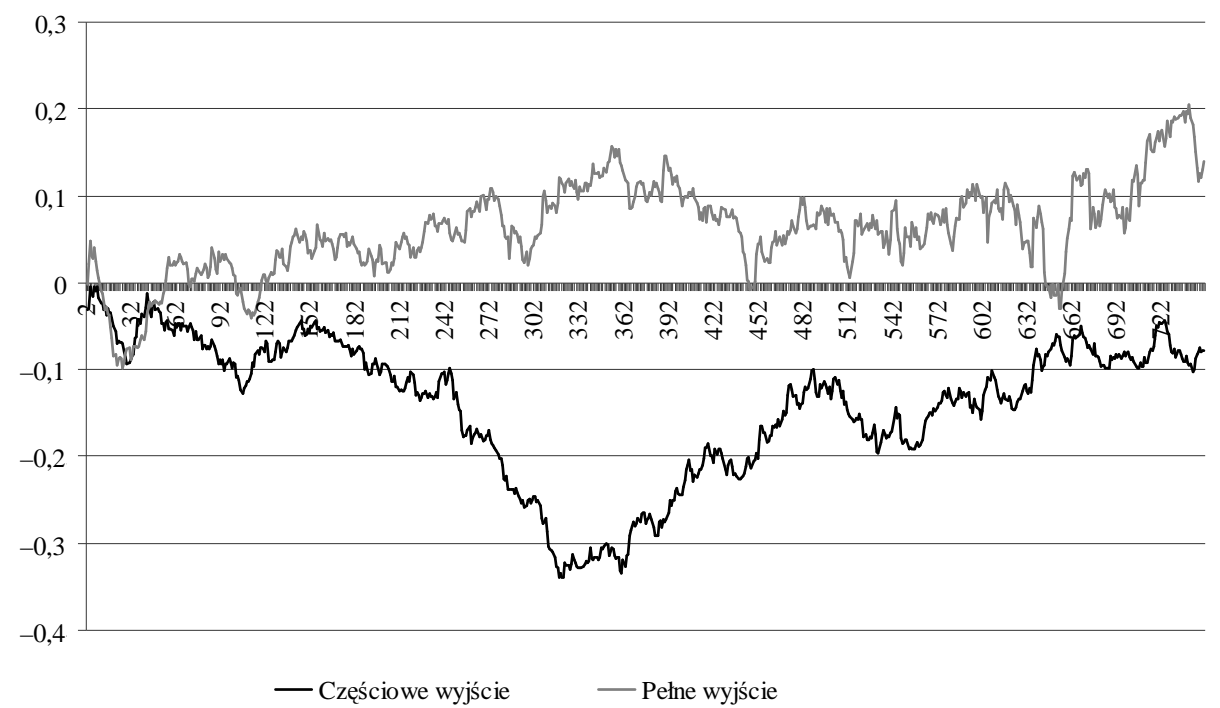

Rys. 4. Skumulowane anormalne stopy zwrotu z akcji spółek portfelowych funduszy private equity dla pierwszych ofert publicznych w latach 2002-2010 według przyjętej strategii częściowego lub pełnego wyjścia z inwestycji

Źródło: jak do rys. 3.

Na podstawie danych przedstawionych na rys. 4 można wskazać, iż skumulowane anormalne stopy zwrotu z akcji spółek wobec których zastosowana została strategia pełnego wyjście $\mathrm{z}$ inwestycji funduszu private equity, w większo- 
ści analizowanych dni notowań giełdowych kształtowały się na dodatnim poziomie. Z kolei skumulowane stopy zwrotu z akcji spółek, w przypadku których fundusze private equity zdecydowały się kontynuować zaangażowanie kapitałowe po upływie 1 roku licząc od dnia debiutu giełdowego w całym analizowanym okresie wskazywały wartości ujemne. Ponadto można zauważyć, iż w początkowym okresie notowań giełdowych analizowanych spółek (do około 40 dnia notowań) skumulowane anormalne stopy zwrotu z akcji obu grup spółek kształtowały się w zbliżony sposób. Dopiero w późniejszym okresie wyraźnie zauważalna są odmienne tendencje $\mathrm{w}$ zakresie odnotowanego poziomu skumulowanych anormalnych stóp zwrotu w zależności od zastosowanej strategii dezinwestycji funduszy private equity.

\section{ZAKOŃCZENIE}

Redukcja zaangażowania kapitałowego funduszu private equity w przedsiębiorstwo udziałowe osiagana przez wprowadzenie akcji spółki do obrotu giełdowego, a następnie ich sprzedaż za pośrednictwem publicznego rynku papierów wartościowych przybiera zróżnicowany zakres. W warunkach polskiego rynku kapitałowego dominującą rolę odgrywa strategia częściowego wyjścia $\mathrm{z}$ inwestycji funduszu private equity. Całkowita redukcja zaangażowania kapitałowego funduszu w przedsiębiorstwo udziałowe $\mathrm{z}$ reguły następuje po upływie ponad 1 roku od debiutu giełdowego spółki portfelowej na Giełdzie Papierów Wartościowych w Warszawie.

Badania nad rynkowymi rezultatami implementacji strategii częściowego i pełnego wyjścia z inwestycji funduszy private equity metodą pierwszej oferty publicznej wskazały na występowanie zróżnicowanych efektów tych działań. Wśród spółek portfelowych, w których fundusze zrealizowały strategię częściowego wyjścia $z$ inwestycji w ramach pierwszej oferty publicznej zaobserwowano niższe wartości skumulowanych anormalnych stóp zwrotu $\mathrm{z}$ akcji w porównaniu z pozostałymi spółkami objętymi procesami dezinwestycji za pośrednictwem publicznego rynku papierów wartościowych. Otrzymane wyniki wzmacniają przypuszczenie, iż przyczyną występowania odmiennego kształtowania się kursów akcji spółek portfelowych funduszy private equity wprowadzonych do publicznego obrotu w celu realizacji procesów dezinwestycji może być ryzyko związane z dodatkową podażą akcji z portfela inwestycyjnego funduszu private equity. 


\section{BIBLIOGRAFIA}

B lack B. S., Gils on R. J., Venture capital and the structure of capital markets: Banks versus stock markets, ,Journal of Financial Economics” 1998, vol. 47.

B oulton T. J., S mart S. B., Zutter C. J., IPO underpricing and international corporate governance, ,Journal of International Business Studies” 2010, vol. 41.

Coch $\mathrm{r}$ a n J. H., The risk and return of venture capital, „Journal of Financial Economics” 2005, vol. 75.

Cumming D. J., Fleming G., Schwienbacher A., Liquidity Risk and Venture capital Finance, „Financial Management” 2005, vol. 34, issue 4.

$\mathrm{Cumming}$ D. J., Mac Intosh J. G., Venture capital investment duration in Canada and the United States, ,Journal of Multinational Financial Management” 2001, vol. 11.

$\mathrm{Cumming} \mathrm{D.,} \mathrm{Joh} \mathrm{an} \mathrm{S.,} \mathrm{Information} \mathrm{asymmetries,} \mathrm{agency} \mathrm{costs} \mathrm{and} \mathrm{venture} \mathrm{capital} \mathrm{exit} \mathrm{out-}$ comes, „Venture capital” 2008, vol. 10, no. 3.

EVCA Yearbook 2003-2011, European Private Equity \& Venture Capital Association, Zaventem, Belgium.

Fenn G. W., Liang N., Prowse S., The Economics of the Private Equity Market, „Federal Reserve Bulletin", January 1996.

Glad st on e D., Glad st on e L., Venture capital Handbook: An Enterpreneur's Guide to Raising Venture capital, Financial Times Prentice Hall, Londyn-New York 2001.

Go mpers P., Grandstanding in the venture capital industry, „Journal of Financial Economics” 1996, vol. 42.

Gompers P., Lerner J., The Venture capital Cycle, MIT Press, Cambridge Massachusetts 2006.

Gompers P., Optimal Investment, Monitoring, and the Staging of Venture capital, „Journal of Finance" 1995, vol. 50, issue 5.

Hochberg Y. V., Ljung qvist A., Lu Y., Venture Capital Networks and Investment performance, ,The Journal of Finance” 2007, vol. 62, no. 1.

Hsu D. H., What Do Entrepreneurs Pay for Venture capital Affiliation?, „The Journal of Finance", August 2004, vol. LIX, no. 4.

Jobman D. R., The Handbook of Alternative Investment, John Wiley\&Sons, Inc., New York 2002.

Lewandowska L., Niekonwencjonalne formy finansowania przedsiębiorczości, ODiDK Sp. z o.o., Gdańsk 2000.

Lind se y L., The Venture Capital Keiretsu Effect: An Empirical Analysis of Strategic Alliances Among Portfolio Firms, SIEPR Discussion Paper No. 02-17, Stanford University, November 2002.

Lj ung q vist A., IPO underpricing, [w:] B. E. Ec kbo (red.), Handbook of Corporate Finance: Empirical Corporate Finance, 2006, vol. A, chapter 7.

Loughran T., Ritter J. R., Rydqvist K., Initial public offerings: International insights, „Pacific-Basin Finance Journal” 1994, vol. 2.

Mackinlay A. C., Event Studies in Economics and Finance, „Journal of Economic Literature”, March 1997, vol. XXXV.

Meggins on W. L., Weiss K. A., Venture capitalists certification in initial public offerings, „Journal of Finance” 1991, vol. 46.

Ortgiese J., Value Added by Venture Capital Firms, JOSEF EUL VERLAG, Lohmar-Köln 2007.

P a f fil M., Fundusze private equity. Wptyw na wartość spótki, Difin, Warszawa 2005.

Panfil M., Globalizacja inwestycji venture capital, [w:] A. Szablewski (red.), Migracja kapitatu w globalnej gospodarce, Difin, Warszawa 2009. 
Povaly S., Private equity exits: Divestment process management for leveraged buyouts, Springer, Berlin Heidelberg 2007.

S ob ań ska K., S i er ad zan P., Inwestycje private equity/venture capital, Key Text, Warszawa 2004.

S o snow ski T., Uwarunkowania decyzji funduszy private equity o wyborze metody dezinwestycji, [w:] J. D u raj (red.), Prace z zakresu ekonomiki i zarzqdzania przedsiębiorstwem, „Acta Universitatis Lodziensis”, Folia Oeconomica 256, Wydawnictwo Uniwersytetu Łódzkiego, Łódź 2011.

S u k a c z D, Pierwsze oferty publiczne na rynkach kapitatowych, CeDeWu.pl, Warszawa 2005.

Survey of the Economic and Social Impact of Venture Capital in Europe, Research Paper EVCA, Zaventem, Belgium 2002.

$\mathrm{S}$ w e d ro e L. E., Kizer J., The only guide to alternative investments you'll ever need, Bloomberg Press, New York 2008.

W all J., S mi th J., Better exits, Price Waterhouse Corporate Finance for EVCA, 1997.

Wrzesiński M., Kapitat podwyższonego ryzyka. Proces inwestycyjny i efektywność, Szkoła Główna Handlowa w Warszawie, Warszawa 2008.

Z a sęp a P., Venture capital - sposoby dezinwestycji, CeDeWu.pl Wydawnictwa Fachowe, Warszawa 2010.

Tomasz Sosnowski

\section{MARKET EFFECTS OF PARTIAL AND FULL DIVESTMENT OF PRIVATE EQUITY FUNDS BY INITIAL PUBLIC OFFERING}

The main aim of this paper is to assess the market effects of private equity funds' divestments carried out by an initial public offering on the Warsaw Stock Exchange. The major hypothesis stating that in companies where the full exit of private equity fund strategy has been applied are observed a higher long-term rates of return on stocks compared to the portfolio companies of private equity funds with partial exit from the investment, has been positively verified in this paper. The observed trends were lasting and persisted three years after initial public offering. Empirical research has been carried out on a group of 26 portfolio companies of private equity funds, which initial public offering on the Warsaw Stock Exchange took place in the years 2002-2010.

Key words: private equity, divestment, initial public offering, full exit, partial exit. 